\title{
Microwave assisted rice husk based activated carbon for adsorption of methylene blue dye
}

\author{
Mohd Azmier Ahmad ${ }^{1,3 *}$, Nor Irwin Basir ${ }^{1}$ and Nasehir Khan EM Yahaya ${ }^{2}$ \\ ${ }^{1}$ School of Chemical Engineering, Engineering Campus, UniversitiSainsMalaysia, 14300 NibongTebal, Penang, Malaysia \\ ${ }^{2}$ National Hydraulic Research Institute of Malaysia, Lot 5733 Jalan Putra Permai, 43300 Seri Kembangan, Selangor, Malaysia \\ ${ }^{3}$ Solid Waste Management Cluster, Science \& Engineering Research Centre, Engineering Campus, UniversitiSains Malaysia, \\ NibongTebal, Penang, Malaysia
}

\section{Article Info \\ *Corresponding author: \\ Mohd Azmier Ahmad \\ School of Chemical Engineering \\ Engineering Campus, Universiti Sains \\ Malaysia \\ 14300 Nibong Tebal \\ Penang, Malaysia \\ Tel: +604 5996459 \\ Fax: +6045996908 \\ E-mail: chazmier@usm.my}

Received: July 25, 2018

Accepted: July 31, 2018

Published: August 5, 2018

Citation: Ahmad MA, Basir NI, Yahaya NKEM. Microwave assisted rice husk based activated carbon for adsorption of methylene blue dye Int J Petrochem Res. 2018; 2(2): 162-164.

doi: 10.18689/ijpr-1000128

\begin{abstract}
Copyright: (c) 2018 The Author(s). This work is licensed under a Creative Commons Attribution 4.0 International License, which permits unrestricted use, distribution, and reproduction in any medium, provided the original work is properly cited.
\end{abstract}

Published by Madridge Publishers

\begin{abstract}
Rice husk based activated carbon (RHAC) was prepared for the methylene blue (MB) dye adsorption through physical activation process which involved microwave irradiation and carbon dioxide gasification. The effect of initial dye concentration and contact time were evaluated in a batch process. The MB adsorption onto RHAC was found to increase from 16.18 to $137.15 \mathrm{mg} / \mathrm{g}$ as the $\mathrm{MB}$ concentrations increase from 25 to $300 \mathrm{mg} / \mathrm{L}$. The adsorption equilibrium data was best fitted into Freundlich isotherm model.
\end{abstract}

Keywords: Activated carbon, Adsorption, Methylene blue, Microwave heating, Rice husk

\section{Introduction}

The textile is one of the largest water consuming industries and releases large amount of effluent. The textile effluent contains carcinogenic dye, toxic heavy metals, phenolic compounds, softeners and other chemicals used in the dyeing process [1]. The presences of even very low concentration of dye in the effluent are highly visible and undesirable. Dye is very much associated with carcinogenic, mutagenic, allergenic and toxic properties [2]. Dye is difficult to be decolorized and decomposed biologically. Therefore, the dye wastewater needs to be properly treated before its release into the environment [3]. Activated carbon (AC) adsorption is considered as one of the most effective method for dye wastewater treatment [4]. In this study, rice husk was used to produce $\mathrm{AC}$ using microwave heating and $\mathrm{CO}_{2}$ gasification for $\mathrm{MB}$ dye removal from aqueous solution.

\section{Methodology}

The rice husk was placed in tubular reactor and carbonized using vertical furnace at temperature of $350^{\circ} \mathrm{C}$ for 30 minutes under the nitrogen flow of $150 \mathrm{ml} / \mathrm{min}$. Then the char produced was placed in a Pyrex glass reactor in the chamber of the microwave oven. The microwave irradiation was carried at radiation time and radiation power of 4.28 minutes and microwave power of 440 watt under $\mathrm{CO}_{2}$ flow of $150 \mathrm{ml} / \mathrm{min}$.

For adsorption study, the $1 \mathrm{~g} / \mathrm{L}$ of MB stock solution was prepared by dissolving $1 \mathrm{~g}$ of MB dye powder (Sigma-Aldrich (M) Ltd) with 1 litre of deionized water. $0.2 \mathrm{~g}$ of the RHAC was added to a series of Erlenmeyer flask filled with $0.2 \mathrm{~L}$ of MB dye solution with different initial concentrations ranging from $25-300 \mathrm{mg} / \mathrm{L}$. The solutions were kept in an isothermal water bath shaker at temperature $30^{\circ} \mathrm{C}$ and shaker speed of $60 \mathrm{rpm}$. The aqueous samples were then withdrawn at the equilibrium state of 24 hours. The MB concentration was measured at $664 \mathrm{~nm}$ by using UV-Vis spectrometer (Model Shimadzu 
UV-1800, Japan). The amount of MB adsorbed on the surface of RHAC at equilibrium was calculated using following equation:

$\mathrm{q}_{\mathrm{e}}=\frac{\left(\mathrm{C}_{\mathrm{o}}-\mathrm{C}_{\mathrm{e}}\right) \mathrm{V}}{\mathrm{M}}$

$\mathrm{Q}_{\mathrm{e}}=$ Amount of $\mathrm{MB}$ adsorbed on the RHAC at equilibrium (mg/g)

$\mathrm{C}_{\mathrm{o}}=$ Initial dye concentration $(\mathrm{mg} / \mathrm{L})$

$\mathrm{C}_{\mathrm{e}}=$ Liquid phase dye concentration at equilibrium $(\mathrm{mg} / \mathrm{L})$

$\mathrm{V}=$ Volume of solution $(\mathrm{L})$

$\mathrm{M}=$ Mass of adsorbent $(\mathrm{g})$

The Langmuir and Freundlich adsorption isotherm models were used to fit the experimental data obtained throughout this study. The Langmuir model assumes that monolayer coverage occurs on the surface. The Langmuir isotherm equation can be expressed as [5]:

$\mathrm{q}_{\mathrm{e}}=\frac{\mathrm{q}_{\mathrm{m}} \mathrm{K}_{L} \mathrm{C}_{\mathrm{e}}}{1+\mathrm{K}_{L} \mathrm{C}_{\mathrm{e}}}$

By rearranging the equation:

$\frac{\mathrm{C}_{\mathrm{e}}}{\mathrm{q}_{\mathrm{e}}}=\frac{1}{\mathrm{q}_{\mathrm{m}}} \mathrm{C}_{\mathrm{e}}+\frac{1}{\mathrm{~K}_{\mathrm{L}} \mathrm{q}_{\mathrm{m}}}$

where,

$\mathrm{C}_{\mathrm{e}}=$ Equilibrium concentration of $\mathrm{MB}(\mathrm{mg} / \mathrm{L})$

$\mathrm{q}_{\mathrm{m}}=$ Monolayer adsorption capacity of the adsorbent $(\mathrm{mg} / \mathrm{g})$

$\mathrm{K}_{\mathrm{L}}=$ Langmuir adsorption constant (L/mg).

Equation 3 shows the linear form of Langmuir isotherm. Straight line graph of $C_{e} / q_{e}$ against $C_{e}$ can be plotted with slope $1 / q_{m}$ and intercept of $1 / K_{L} q_{m}$.

Freundlich isotherm is used to correlate the equilibrium data for multilayer adsorption on rough surface. This isotherm can describe heterogeneous systems and is expressed as follows [6]:

$\mathrm{q}_{\mathrm{e}}=\mathrm{K}_{\mathrm{F}} \mathrm{C}_{\mathrm{e}}^{\frac{1}{\mathrm{n}_{\mathrm{F}}}}$

which can rearrange into:

$\ln \mathrm{q}_{\mathrm{e}}=\frac{1}{\mathrm{n}_{\mathrm{F}}} \ln \mathrm{C}_{\mathrm{e}}+\ln \mathrm{K}_{\mathrm{F}}$

where,

$\mathrm{n}_{\mathrm{F}} \quad=$ Adsorption intensity

$\mathrm{K}_{\mathrm{F}}=$ Freundlich isotherm constant $\left(\mathrm{mg} / \mathrm{g}(\mathrm{L} / \mathrm{mg})^{1 / n}\right)$

In general, $\mathrm{n}>1$ suggests that adsorbate is favorably adsorbed on the adsorbent. The higher the $\mathrm{n}$ value the stronger the adsorption intensity. By plotting the experimental data on a graph of $\ln q_{e}$ against $\ln C_{e^{\prime}}$ the $1 / n_{F}$ of the adsorption intensity or surface heterogeneity can be determined.

\section{Results and discussion}

Figure 1 shows the effect of contact time and various initial dye concentrations from $25 \mathrm{mg} / \mathrm{L}$ to $300 \mathrm{mg} / \mathrm{L}$ for $\mathrm{MB}$ on the RHAC. The graph obtained shows that the adsorption uptake increased with time. The adsorption was fast at the beginning of contact time due to the fact that a larger number of surface sites are available for adsorption [7]. Then the adsorption became slower before reaching the equilibrium as the repulsion between the solute molecules of the solid and bulk phase occurred. Thus the remaining surface sites were difficult to be occupied [8]. The MB adsorption was increased from 16.18 to $137.15 \mathrm{mg} / \mathrm{g}$ as the MB concentration increased from 25 to $300 \mathrm{mg} / \mathrm{L}$.

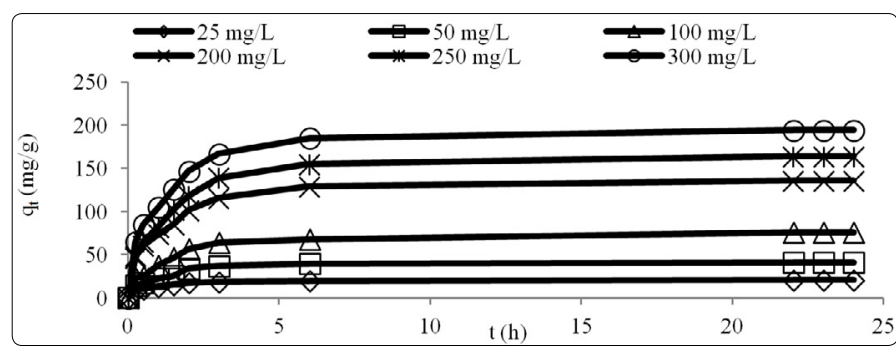

Figure 1. MB dye adsorption uptake versus adsorption time at various initial concentrations at $30^{\circ} \mathrm{C}$

The effect of initial dye concentration relies on the available binding sites on the adsorbent surface. The increased in initial dye concentration caused higher driving force of mass transfer between adsorbate and adsorbent [3]. Three consecutive mass transport steps are associated with the adsorption of the solute from the solution by porous adsorbent. First, the adsorbate migrates through the solution by film diffusion, followed by the solute movement from the particle surface into the interior site by pore diffusion and finally the adsorbate is adsorbed into the active sites at the interior of the adsorbent particle [9]. The linearized form of Langmuir and Freundlich isotherm models are shown in Figure 2. Table 1 summarizes all the constants obtained for MB adsorption on RHAC for both models.

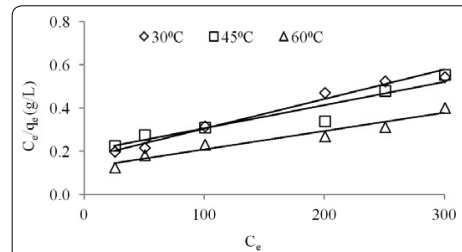

(a)

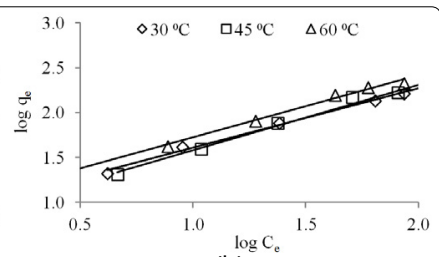

(b)
Figure 2. MB dye adsorption onto RHAC; (a) Langmuir and (b) Freundlich

Table 1. Isotherm parameter for adsorption of MB by RHAC at $30^{\circ} \mathrm{C}$

\begin{tabular}{|c|c|}
\hline Langmuir & Freundlich \\
\hline $\mathrm{q}_{\mathrm{m}}=321.4 \mathrm{mg} / \mathrm{g}$ & $\mathrm{n}_{\mathrm{F}}=1.51$ \\
$\mathrm{~K}_{\mathrm{L}}=0.008 \mathrm{~L} / \mathrm{mg}$ & $\mathrm{K}_{\mathrm{F}}=8.814 \mathrm{mg} / \mathrm{g}(\mathrm{L} / \mathrm{mg}) 1 / \mathrm{n}$ \\
$\mathrm{R}^{2}=0.977$ & $\mathrm{R}^{2}=0.995$ \\
\hline
\end{tabular}

Based on the $R^{2}$ values, the adsorption isotherm fitted the data in the order of Freundlich> Langmuir, indicating the multilayer nature on heterogeneous surface of adsorption process of MB onto RHAC. Relatively high $n_{F}$ values of 1.51 and $K_{F}$ values of 8.814 , denoting high adsorption intensity and adsorption capacity [9]. RHAC was found to have high maximum monolayer capacity of $321.4 \mathrm{mg} / \mathrm{g}$.

\section{Conclusion}

In the present study, the adsorption of MB dye was found to increase with increase in contact time and dye initial concentration. Isotherm study of MB onto RHAC was best 
fitted by Freundlich isotherm model which indicated multilayer adsorption process occurred on heterogeneous surfaces. Rice husk was shown to be a promising low-cost material for the production of RHAC with high efficiency in removing MB dye from aqueous solution.

\section{Acknowledgements}

The authors are grateful for the funding from Solid Waste Management Cluster (RU 1001/CKT/870023) and Bridging Grant of Universiti Sains Malaysia.

\section{References}

1. Isah UA, Abdulraheem G, Bala S, Muhammad S, Abdullahi M. Kinetics, equilibrium and thermodynamics studies of C.I. Reactive Blue 19 dye adsorption on coconut shell based activated carbon. International Biodeterioration and Biodegradation. 2015; 102: 265-273. doi: 10.1016/j. ibiod.2015.04.006

2. Islam MA, Sabar S, Benhouria A, Khanday WA, Asif M, et al. Nanoporous activated carbon prepared from karanj (Pongamiapinnata) fruit hulls for methylene blue adsorption. Journal of the Taiwan Institute of Chemical Engineers. 2017; 74: 96-104. doi: 10.1016/j.jtice.2017.01.016
3. Kono $H$. Preparation and characterization of amphoteric cellulose hydrogels as adsorbents for the anionic dyes in aqueous solutions. Gels. 2015; 1(1): 94-116. doi: 10.3390/gels1010094

4. Goswami M, Phukan P. Enhanced adsorption of cationic dyes using sulfonic acid modified activated carbon. Journal of Environmental Chemical Engineering. 2017; 5(4): 3508-3517. doi: 10.1016/j.jece.2017.07.016

5. Langmuir I. The adsorption of gases on plane surfaces of glass, mica and platinum. Journal of the American Chemistry Society. 1918; 40(9): 13611403. doi: $10.1021 / \mathrm{ja} 02242 \mathrm{a} 004$

6. Freundlich HMF. Over the adsorption in solution. Journal of Physical Chemistry.1906; 57: 385-470.

7. Agarwal S, Gupta VK, Ghasemi M, Azimi-Amin J. Peganumharmala-L seeds adsorbent for the rapid removal of noxious brilliant green dyes from aqueous phase. Journal of Molecular Liquids. 2017; 231: 296-305. doi: 10.1016/j. molliq.2017.01.097

8. Zhou L, Yu Q, Cui Y, Xie F, Li W, Li Y, et al. Adsorption properties of activated carbon from reed with a high adsorption capacity. Ecological Engineering. 2017; 102: 443-450. doi: 10.1016/j.ecoleng.2017.02.036

9. Ahmad MA, Afandi NS, Adegoke KA, Bello OS. Optimization and batch studies on adsorption of malachite green dye using rambutan seed activated carbon. Desalination and Water Treatment. 2015; 57: 2148721511. doi: 10.1080/19443994.2015.1119744 